WIDER Working Paper 2017/24

\title{
Political economy and governance
}

Evelyn Dietsche*

January 2017 
Abstract: This paper reviews the political economy of extractive resources and the associated resources sector governance agenda. The consensus that good sector governance improves the developmental impacts of extractive resources exploitation is premised on the understanding that institutions matter for development. However, there is no straightforward answer to the question of what exactly 'institutions' are, how they change, or how they can be made to change to become more supportive of an extractives-led development agenda. The paper suggests reframing the political economy of extractive resources away from the negative question how can poor outcomes be prevented? and towards the positive question how can positive institutional change for better outcomes be brought about?. It organizes and presents the main strands of a substantial body of literature that can help to inform answers to these questions.

Keywords: natural resources, extractive industries, political economy, governance, institutions JEL classification: Q32, P48, P16, O43, B52

Acknowledgements: The author would like to thank and acknowledge Alan Roe and Tony Addison for their constructive feedback and suggestions on an earlier version of this paper.

*Chatham House, London, UK, evelyn.dietsche@dietschepolicy.com

This study has been prepared within the UNU-WIDER project on 'Extractives for development (E4D)', which is part of a larger research project on 'Macro-economic management (M-EM)'.

Copyright (C) UNU-WIDER 2017

Information and requests: publications@wider.unu.edu

ISSN 1798-7237 ISBN 978-92-9256-248-9

Typescript prepared by Joseph Laredo.

The United Nations University World Institute for Development Economics Research provides economic analysis and policy advice with the aim of promoting sustainable and equitable development. The Institute began operations in 1985 in Helsinki, Finland, as the first research and training centre of the United Nations University. Today it is a unique blend of think tank, research institute, and UN agency — providing a range of services from policy advice to governments as well as freely available original research.

The Institute is funded through income from an endowment fund with additional contributions to its work programme from Denmark, Finland, Sweden, and the United Kingdom.

Katajanokanlaituri 6 B, 00160 Helsinki, Finland

The views expressed in this paper are those of the author(s), and do not necessarily reflect the views of the Institute or the United Nations University, nor the programme/project donors. 
More than ten years ago, the World Bank's Extractive Industry Review (EIR) marked the beginning of a consensus that 'governance' matters for the developmental outcomes producer countries can achieve from exploiting extractive resources (IFC 2003). ${ }^{1}$ Led by an independent commission, the EIR recommended that the World Bank Group and other development finance institutions should refrain from supporting extractive resources projects unless producer countries had 'good governance' in place. The World Bank's Board moderated this recommendation, arguing that, even where governance was deficient, multilateral organizations had a positive role to play. They could help producer countries to improve governance and exercise influence to improve industry standards.

At the time, it was already well understood that producer countries often faced macroeconomic challenges and that, to manage these, they could draw on technical support from the international financial organizations. But there also was growing awareness that the extractive resources sector presented serious political-economic challenges. In particular, in the presence of windfall resource rents, self-interested politicians and bureaucrats might be tempted to use these rents for private gain, thus undermining the positive economic and social impacts that the sector could otherwise have.

As discussed in the paper by Lahn and Stevens (2017, forthcoming), this reasoning gave rise to a second consensus, namely that improving sector governance would mitigate this politicaleconomic challenge. Over the past decade, this consensus has experienced a remarkable elevation. Endorsed at the inter-governmental level, it has nurtured the emergence of several international initiatives and dedicated non-governmental organizations (NGOs) diligently working towards improving sector governance.

At the same time, 'governance' as a concept has been subject to much criticism. On the positive side, it has been argued that the term has provided the international development community with a reference point to discuss all things political. It has allowed practitioners to reflect upon the political economy of government policies and decision-making to identify why well meant technical reforms have often not led to the expected developmental outcomes (Ahrens 2000; Dietsche 2003). It has also called attention to the institutional underpinnings of effective economic and political management (Grindle 2010).

But the term has also meant different things to different constituencies. ${ }^{2}$ Drawing on the broader public policy literature, Hyden et al. (2004) found that comparative political scientists had used the term to find out how different rules affect results. Meanwhile, international relations scholars had used it to look at how processes deliver rules. Scholars of public administration had focused on steering processes towards desired results. International development agencies hoped that governance could serve as a tool to deliver positive developmental impacts.

\footnotetext{
${ }^{1}$ The World Bank Group initiated the EIR in June 2000, following its annual meeting in Prague, at which the Group's President, James Wolfensohn, promised to review the Bank's role in the extractive industries in response to criticism from the non-governmental community about the Group's involvement in this sector and the fight against poverty. The former Minister of the Environment for Indonesia, Dr Emil Salim, was appointed in July 2001 to head this multistakeholder review. The EIR was concluded in 2004.

2 See Gisselquist (2012) for a comprehensive review of the different definitions put forth.
} 
Unsurprisingly, 'governance' has remained a contested concept. Some argue that things started to go wrong when proponents sought to operationalize 'good governance' to shape policy reform programmes and apply respective 'conditionalities' (Ahrens 2002; Gisselquist 2012). International development organizations, for example, tried to apply insights gained from institutional analyses that focused on OECD countries to support development in non-OECD countries (Opper 2008). Mkandawire (2012) finds that reform programmes introduced under the banner of good governance have supported 'institutional mono-cropping and mono-tasking'. In other words, such programmes have assumed that blueprint and standardized interventions can be applied to every country context to deliver similar results. Fukuyama (2013) observes that reform proposals have predominantly tried to impose institutions that limit or check power and constrain politicians. He argues that much less effort has been put into helping countries build the capacity required to provide public goods and services to citizens and support private sector development. Similarly, Andrews (2013), who has reviewed the mixed outcomes resulting from reforms targeted at improving the governance of public finances, concludes that the concept has been poorly conceptualized in relation to the complexity of insights gained from institutional analyses on the process of institutional change. Finally, Grindle (2010) argues that the popularity of the idea of good governance has outpaced its capacity to deliver. ${ }^{3}$

Contrasting these criticisms with the global agenda on the good governance of the extractive resources sector raises the question of whether that agenda has taken proper account of the concerns raised. This paper argues that the proposition that 'good governance' somehow matters for positive outcomes has been derived from institutional analyses suggesting that institutions matter'. But unfortunately it is less clear how institutions actually get changed. Therefore, the paper suggests reframing the political economy of extractive resources from the negative question how can poor outcomes be prevented? to the positive question how can positive institutional change for better outcomes be brought about?. Not only does this latter question build on the question posed by Lahn and Stevens in their paper 'The curse of the one-size-fits-all fix: re-evaluating what we know about extractives and economic development' (2017), namely why did extractive resources not help countries to grow the rest of their economies?; it also prepares for Dietsche (2017, forthcoming), which is on the proposed use of industrial policy as a means to diversify economies away from dependence on the extractive resources sector.

The remainder of the paper is structured in four parts. Section 2 reviews why it has been found that institutions matter for the political economy of extractive resources and how this finding has informed the resources governance agenda. Section 3 explores what institutions are and introduces a framework that highlights where substantial gaps in knowledge remain. It applies this framework to, and assesses the gaps in relation to, the extractive resources sector. Section 4 discusses two critical issues on the political economy of extractive resources and provides a framework for assessing the contributions third parties make to these. Section 5 concludes.

\section{The political economy of extractive resources and institutions}

The international debate on extractive resources and the developmental impacts of their exploitation rests on the consensus that 'governance matters'. This section tracks the origins of

\footnotetext{
${ }^{3}$ For an in-depth discussion on this challenge see Lant Pritchett's contribution to the UNU-WIDER Annual Lecture 2012: https://www.wider.unu.edu/video/wider-annual-lecture-16 (accessed 4 July 2016).
} 
this consensus to the need to explain variance in outcomes across producer countries and the role that institutional analyses have played in nurturing the good governance consensus.

\subsection{Explaining negative outcomes}

Research on the political economy of extractive resources dates back to the mid-1990s, and there are several reviews that have surveyed the literature over the years, including most prominently Ross (1999) and Rosser (2006a, 2006b), but also several others (Auty 2001; Barma et al. 2012; Benner et al. 2010; Dietsche 2007; Humphreys et al. 2007; Melia 2015; Ostrowski 2013; Stevens and Dietsche 2008; Van der Ploeg 2008; Weinthal and Luong 2006).

For a start, it is worth remembering that the political economy of extractive resources drew its inspiration from the desire to explain why many countries reliant on producing such resources had experienced negative economic, political, and social outcomes (Rosser 2006a). Ross (1999) observed that economists and political scientists had approached this issue in different ways. While the latter had conducted in-depth case studies, the former had applied cross-country statistical analyses to understand why resource-rich countries had generally experienced worse economic, political, and social outcomes than other countries.

The seminal paper by Sachs and Warner (1995) on natural resource abundance and economic growth was critical in drawing attention to the question of why resource-rich countries had not achieved better economic outcomes. It contradicted the mainstream policy advice of the 1980s that countries could improve their economic situations if they encouraged investment in the resources sector. Their analysis intensified the awareness that economic dependence on the resources sectors harbours macroeconomic risks and can adversely affect other economic sectors. ${ }^{4}$ Initially, confidence was placed in the ability of technocrats in central banks and finance ministries to manage these risks, if necessary with help from international financial institutions. However, the observation that many countries nevertheless did not achieve better economic outcomes prompted a search for explanations as to why this was the case.

First, economists and political scientists set off to reconfirm that resource-rich countries had indeed suffered from worse economic performance. ${ }^{5}$ Relying on cross-country statistical analyses, they built on standard economic growth models to confirm that the proxies they deployed for measuring 'resource dependence' did indeed show as 'significant' in explaining the variance in economic performance between resource-rich and non-resource-rich countries.

To make sense of the statistical findings, economic and political science researchers then applied microeconomic analysis to the politics of extractive resources. Assuming that politicians and bureaucrats were rational individuals maximizing their self-interests, they conjectured that there may be good reasons why the governments of resource-rich countries were unwilling, or even unable, to adopt policies that would counter the macroeconomic risks and maximize the development impacts associated with the resources sectors. The conclusion was that unproductive rent-seeking behaviour by politicians and bureaucrats could be causing the poor outcomes. Formal models were built to test more specific hypotheses, applying multiple regression analyses. For example, Robinson et al. (2006) used a probabilistic voting model to show why politicians tend to over-extract. It was concluded that allowing self-interested politicians and bureaucrats to gain unfettered access to the rents generated by the resources sectors would invariably result in some

\footnotetext{
${ }^{4}$ For early work on the macroeconomic risks associated with economic dependence on the resources sectors, see Gelb (1986) and Pinto (1987).

${ }^{5}$ For a detailed review of this literature see Dietsche (2014).
} 
form of 'state failure'. In other words, 'poor governance' had caused the poor economic performance.

The next step was to hypothesize that economic dependence on the resources sector also results in 'bad' political regimes. One line of enquiry was whether greater fiscal dependence on resources revenues makes for worse political outcomes, as such dependence may nurture unfortunate alliances between political and economic elites, who will collaborate to uphold 'bad' political regimes to serve their particular interests (Bräutigam et al. 2008; Dijohn 2007; Moore 2004). Another line of enquiry was whether resource-rich countries were more likely to backtrack from positive gains made in transiting political regimes towards more democratic forms of governance (Jenson and Wantchekon 2004).

Finally, some scholars explored whether the presence of a resources sector could be associated with negative social outcomes. The worst of all such outcomes, namely conflicts and civil wars, raised particular concern. Several comparative and country case studies investigated what potential causal mechanisms linked resources to different types and characteristics of conflicts (Collier and Hoeffler 2004; Humphreys 2005; Ross 2004a, 2004b; Snyder 2006). A further concern was whether economic dependence on the resources sector increased inequality, either by widening the gap between the richest and poorest of a country, or by widening the gap between the richer and poorer regions of a country (Ross 2007).

All of this work faced the challenge of contributing to a mixed picture. Quantitative studies faced the methodological problem that their results were found to be very sensitive to the proxies they used for measuring resource sector dependence (Brunnschweiler and Bulte 2008; Haber and Menaldo 2011). Refinements to these proxies suggested that some countries had performed better than others and therefore, at least, the inevitability of negative outcomes could be questioned, but there were more fundamental concerns about the suitability of the proxies used (Andrews 2013; Arndt and Oman 2006; Van de Walle 2005).

Qualitative studies also pointed to mixed results. For example, Botswana, Chile, and Peru have shown improvements in both economic performance and social indicators, while other countries have stagnated or deteriorated (Davis and Vásquez Cordano 2012). Some scholars went further by developing theories of the political economy of resources in an attempt to explain both good and bad outcomes (Jones Luong and Weinthal 2010; Snyder 2006).

\subsection{Explaining variance in outcomes}

The mixed results suggested that the causal mechanisms responsible for the negative outcomes were not straightforward and that scholars had struggled to penetrate the complexity of causes and effects (see also Lahn ans Stevens 2017). For example, the proxies used to measure political regime type had been deployed as a dependent variable (see above), but also as a variable to explain variance in outcomes (Eifert et al. 2003). In addition, national-level outcomes did not always match outcomes at the sub-national level. Sometimes apparent improvements in national-level indicators were not matched by commensurate improvements in outcomes at the sub-national level, or apparent improvements at the sub-national level were not reflected in national-level indicators.

\section{Structural explanations}

The proposition, that poor outcomes were the result of unproductive rent-seeking behaviour by politicians and bureaucrats who had been left unfettered, was countered by a second school of thought that took a closer look at the political-economic power dynamics between different sociopolitical constituencies and how these affect outcomes. Its proponents suggested that structural 
characteristics and the political-economic power relationships that these might evoke were conditioning the decisions of politicians, bureaucrats, and other agents. Thus, rather than relying on a priori assumptions about individuals, the proponents of structural explanations saw decisionmakers embedded in socio-economic and socio-political relationships that, for better or for worse, influenced their behaviour.

The advantage of the structural perspective over the focus on unproductive rent-seeking behaviour was that the latter's proponents could hardly appeal to politicians and bureaucrats to change their rational behaviour in order to prevent negative aggregate outcomes. On the other hand, those supporting the structural perspective could delve deeper into the broader social science research on the role of institutions in economic development. This debate had been brought into the development discourse from the mid-1990s, drawing on various strands of institutional analysis that had emerged in the broader social sciences from around the 1980s, seeking to explain differences in the economic, political, and social trajectories of modern market economies (Hall and Taylor 1996; Immergut 2005; Koelble 1995; North 1990; Thelen 1999; Williamson 1985, 2000). Regression analyses had taken a historical perspective to understanding the institutional underpinnings of similarly successful modern market economies. They drew attention to the variance in institutions across countries, and to how these had developed and underpinned outcomes. Their analysis supported a view that economic development is pre-conditioned by political and social institutions favourable to development. It also indicated that positive institutional change is not the outcome of technocratic reform exercises but is subject to dynamic political-economic processes. Not least, reflections on the transition experiences of the Eastern European and Central Asian countries of the former Soviet Union influenced thinking on the role of institutions in development (Ahrens 2002; Jones Luong and Weinthal 2010).

\section{Structural characteristics}

Among the structural factors identified as likely to affect the political economy of resources are the physical characteristics of different types of resources and the socio-political structures they give rise to. A prominent distinction was drawn between point source and diffuse natural resources (Auty 2001; Auty and Gelb 2001; Isham et al. 2005; Woolcock et al. 2001):

- Characteristic of point source resources are capital intensity and concentrated ownership, typically associated with large and medium-scale oil, gas, and mining projects. In addition, where land rights support large-scale plantations and agro-industrial enterprises producing bulk commodities, such as palm oil, soya beans, sugar cane, corn, or industrial wood, these can also be considered point source resources.

- Diffuse natural resources require little to moderate capital inputs; economic opportunities are more widely disbursed, capital requirements are less intensive, and ownership is less concentrated. Diffuse resources typically include medium-sized and small farming, but could also include small and artisanal mining.

The argument has been that point source resources are more likely to nurture socio-political structures that support exclusive coalitions of rent-seeking elites holding onto power that they use to limit non-elites' access to economic opportunities.

Another structural source of variance identified was colonial settlement structures and associated institutional legacies. Acemoglu et al. (2001) observed that European colonial powers developed different colonial-administrative institutions in the territories they occupied, depending on whether the prevalence of tropical diseases discouraged European settlers from staying or whether the absence of such diseases encouraged them to stay. Where settlers stayed, they typically developed institutions that encouraged investment more generally. For example, they adopted the types of 
land and mineral rights that they were already familiar with in their mother countries. Where settlers did not stay in large numbers, they developed institutional arrangements designed to simply extract natural resources and transfer them to the mother country.

Social cohesion versus fractionalization provided a third source of institutional variance (Hodler 2004; Perälä 2003). Political elites are more likely to develop institutional arrangements that protect their particular interests where societies are culturally or ethnically more fractionalized and ruling and/or economic elites are tied together on this basis. In contrast, socially more cohesive societies have been found to generate greater confidence and trust between governments and citizens, resulting in institutional arrangements that grant broader access to economic and social opportunities (Easterly et al. 2006).

Another source of variance is the type of state that producer countries exhibit. Auty and Gelb (2001) have drawn a distinction between stylized 'predatory states' and 'developmental states', characterizing them by their differences in the relationships between ruling elites, the state apparatus, and society at large. They tie these characteristics to conditioning structural factors, such as the types of resources exploited, country size, settlement structure, and population density.

The various structural explanations for institutional variance face two challenges of their own. First, they are not primed to offer immediate solutions that might guide policy interventions, because the structural factors and related institutions they highlight are often hard-wired. Second, building on case studies and small-N comparative studies, these explanations cannot claim universal applicability. Nevertheless, researchers have offered a rich source of historical-economic and socio-economic analyses from which to draw insights into the political economy of institutions.

\subsection{Guiding policy interventions}

The more general turn towards institutions and their role in economic development did not go unnoticed by those more sympathetic to the rent-seeking viewpoint (Congleton et al. 2008). They also turned towards 'institutions' to explain the variance in outcomes across producer countries, by drawing upon the rational choice version of institutional analysis. The basic proposition was that 'good institutions' can interrupt the negative relationship between rational individual actions and poor aggregate outcomes, the argument being that countries can achieve better outcomes from extractive resources if they put in place 'good' institutions to constrain the self-interests of politicians and bureaucrats. These agents would then no longer be able to capture resource rents for private gain. By implication, adopting such institutions would result in better governance of the sector.

To test these hypotheses, proponents looked for proxies for the quality of institutions to use as instrumental variables in their multiple regression analyses. With a positive statistical relationship confirmed, they developed more or less plausible narratives to connect their quantitative results with a convincing storyline. For example, Collier and Goederis (2007) applied a subjectively chosen threshold to the country rankings of the International Country Risk Guide (ICRG) as a proxy for 'good' versus 'bad' governance, and on this basis claimed that resource curse does not occur in countries with 'very good institutions'. Considered critically, however, this approach does not explain why the 17 risk components that make up the ICRG and reflect the concerns of foreign investors indicate 'good [or bad] institutions'. Similarly, Mehlum et al. (2006a, 2006b) applied an institutional quality index composed of an unweighted average of five indexes from Political Risk 
Services $^{6}$ to reflect whether countries have 'producer-friendly' or 'grabber-friendly' institutions. Producer-friendly institutions were defined as those 'where rent-seeking and production are complementary activities', whereas grabber-friendly institutions were those 'where rent-seeking and production are competing activities' (Mehlum et al. 2006a: 3). How this indicator relates to the binary definition has remained unclear.

In summary, it is neither straightforward nor uncontroversial to create indices for institutional quality. However, despite the methodological problems, institutions have unfortunately come to be seen as a principal variable explaining variance in outcomes across producer countries. This consensus has advocated that improving institutions will improve sector governance and, thereby, outcomes. For those sympathetic to the explanation that unproductive rent-seeking behaviour poses the key challenge, the policy conclusion has been rather straightforward: 'good institutions', as in 'good governance', provide the high-level solution to the political 'resource curse'.

Implicitly, it has been assumed that improvements in good governance in the form of positive institutional change should be encouraged. At the practical level, a case could be made for advising countries on the institutions they apparently need in order to improve sector governance.

In sharp contrast, those drawing on structural institutional analyses have remained far less ambitious in putting forth policy conclusions and action agendas (Dietsche 2014). Focused on explaining variance in outcomes, they have looked back and reflected on reasons rather than seeking to identify possible solutions. Perhaps, because they seem more alert to historically evolved country conditions, they have taken a more cautious, if not more pessimistic, stance towards suggesting that institutional arrangements can be changed by external advocacy pressures. On the positive side, their insights provide a sense-check on how difficult it is in practice to encourage positive institutional change and suggest where levers for encouraging such change might be found.

\subsection{Summary}

This section has traced the origins of the consensus on resources governance to the need to explain the variance in outcomes across producer countries and the role that institutional analyses have played in nurturing this consensus. It has highlighted the two dominant views on the role of institutions in improving sector governance. The rent-seeking view sees institutions as a device to constrain the otherwise unfettered, unproductive rent-seeking behaviour of politicians and bureaucrats. The alternative sees them as structures that shape the context within which agents define their interests and determine their actions.

A key distinction between the two views is the attention they pay to time. As discussed by Lahn and Stevens (2017), the first view is primed to look for generic solutions that reduce, or preferably end, rent-seeking and its economic costs. It is, essentially, insensitive to time. Improving governance to improve outcomes becomes a matter of 'institutional choices'. In contrast, the structural view is time-sensitive. It stresses the historical trajectories and path dependencies that shape the processes through which interests are defined and pursued. Improving governance becomes a matter of positive institutional change, which happens over time.

\footnotetext{
${ }^{6}$ See http:/ / www.prsgroup.com/about-us/our-two-methodologies/prs (accessed 30 June 2016).

7 As discussed also in the paper by Lahn and Stevens (2017), United Nations organizations, multilateral development banks, and other multilateral organizations readily embraced the 'good governance' agenda to guide their work on institutional and public policy reforms (Gisselquist 2012).
} 


\section{What are institutions?}

The previous section laid out the basis that the political economy of extractive resources has homed in on 'institutions' as the variable that explains variance in outcomes across resource-rich countries, thus seeing institutions as critical to improving the 'good governance' of the resources sector and, ultimately, outcomes. This section now takes a step back and asks what in fact are institutions?. It argues that answering this question requires an understanding of how social scientists have defined institutions and what they have learned about how institutions affect development. This is a critical, but seriously undervalued, step in understanding how extractives-led development might be possible.

From the late 1980s onwards, institutional analyses experienced a revival because researchers felt a need to explain observed differences in the economic, political, and social trajectories of industrialized countries. Compared with the rest of the world, these countries had experienced similarly impressive gains in living standards, despite obvious differences in their domestic institutional arrangements, which had come about over decades and centuries (Hall and Soskice 2001). These analyses drew attention to the institutional foundations of market economies, which mainstream neoclassical economics had typically chosen to ignore, simply assuming that the institutions in place were the most efficient to be had and that there was no need to look at them in any great detail. Instead, this task was left to scholars of politics, public administration, economic history, and sociology. Consequently, these disciplines have played a key role in rediscovering institutions, building on the foundations that had already been laid in the first half of the 20th century.

The challenge for the revived scholarship on institutions has been that it has comprised a wide spectrum of theories and approaches (Brousseau and Glachant 2008). When, in 2000, Oliver E. Williamson reviewed the progress economists had made on this subject, he observed that their quest for a better understanding of the role of institutions in economic development had resulted 'in a boiling cauldron of ideas' with diverse and contradictory implications for policy advice (Williamson 2000: 610). This led Williamson to develop a framework that maps out the various strands of institutional economics across four levels of social science analysis. The remainder of this paper uses this framework and applies it to the extractive resources sector.

Figure 1 reproduces Williamson's framework, showing that scholars have investigated the impact of institutions on economic, political, and social outcomes at three levels, each shaded in grey. The fourth level captures the world of mainstream neoclassical economics. Each level is explained in turn. 
Figure 1: Williamson's 'economics of institutions'

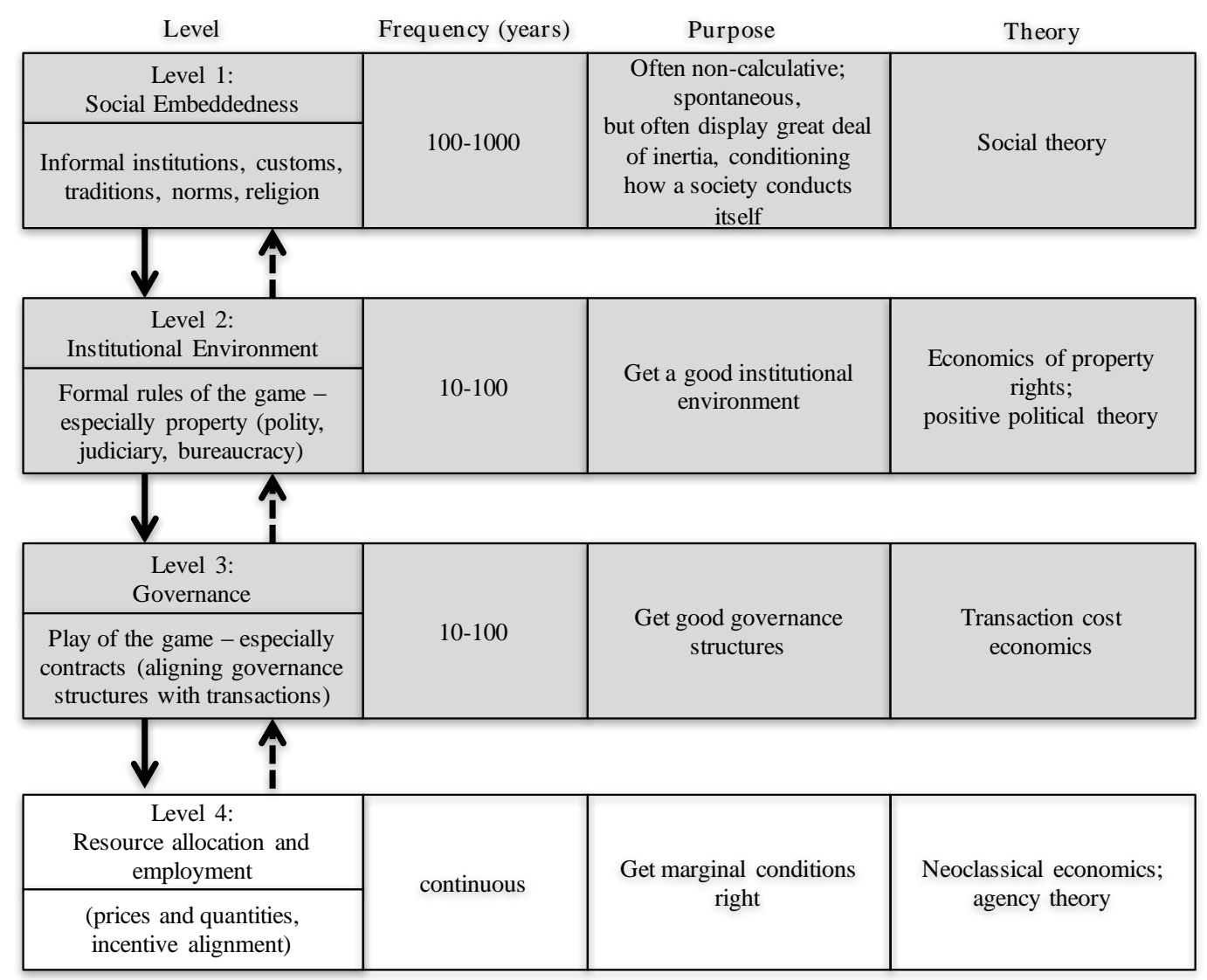

Source: Author's figure, reproduced with permission from Williamson (2000) and Opper (2008).

\section{Level 1: Social embeddedness}

Level 1 is coined after the work of economic sociologist Karl Polanyi (1977 [1944]) and his successor Mark Granovetter (1985) on social and economic transformations. It recognizes that economic systems are ultimately embedded in social networks and relationships. Analyses have focused on the most durable social institutions and their impact on economic decisions-for example, customs, traditions, norms, and religion. Institutions at this level are generally very powerful and typically show a great deal of inertia. Not least, they provide people with the belief systems that shape their understanding of the world around them. They generate trust and reciprocity among social groups beyond immediate kinship. ${ }^{8}$

\section{Level 2: Institutional environment}

This level provides the 'formal rules of the game' for economic transactions. Often, level 2 institutions relate to the territorial remit of sovereign states. Where applicable, they also include international trade and regional economic unions above the level of nation states, as well as subnational states, provinces, or regions where, for example, countries are organized as federations. Thus, this level covers countries' political, bureaucratic, economic, and social systems (and associated property rights and legal and regulatory regimes). The institutions at this level are not

\footnotetext{
${ }^{8}$ Research in evolutionary psychology suggests that humans have needed institutions to maintain social relationships beyond their immediate kinship group and to liberate them from the time-imposed limit on the number of individuals with whom one can have personal relationships. This is the so-called Dunbar number of 150 (Gamble et al. 2014).
} 
expected to change frequently. They may change over decades and perhaps mark distinct political eras.

\section{Level 3: Governance}

Level 3 captures the institutions that formalize the commitments of the parties involved in economic transactions. Williamson called this level 'governance' and described it as the 'play of the game'. It covers the contracts and agreements that underpin market transactions and deal with the risk that parties may cheat or renege on their commitments. Institutions at this level are typically expected to last for a few months or years.

\section{Level 4: Efficient allocation of resources}

Finally, level 4 captures the conventional market analysis whereby the interaction of demand and supply sets prices and Adam Smith's invisible hand is supposed to do its magic. At this level, economic analyses focus on the efficient allocation of scarce resources. The institutional arrangements that work in the background of markets are not assumed to change within the shorter time frames in which market participants make their decisions.

\subsection{Gaps in knowledge}

When Williamson developed this framework over 15 years ago, he used it to identify gaps in knowledge in the study of institutions. Not least, he showed that scholars could well be referring to very different things when they point to 'institutions' as a key determinant of economic outcomes. For example, if they are focused on testing theories using quantitative techniques, they will be prompted to look for features that can be measured and instrumented in statistical analyses. Thus, deploying institutions as an explanatory variable has depended on the availability of proxies for 'institutional quality', encouraging more or less well informed interpretations of what 'good' versus 'bad' institutions are deemed to be.

The next four sub-sections summarize four of the gaps that Williamson identified. In section 3.3, these will be applied to the extractive resources sector.

\section{Institutions connecting across the levels}

One of the gaps is an understanding of how the four levels connect. Williamson observed that each level imposes constraints on the level immediately below it. Figure 1 indicates this with the solid arrows pointing downwards. Thus, how issues are conceived at level 1 conditions how they shape the rules put in place at level 2. These in turn shape the 'play of the game' at level 3, which then affects the allocation of resources at level 4. For example, if at level 1 there is a consensus that private property rights are necessary for value creation, this will be reflected at level 2 . Nation states will uphold private property rights regimes in their constitutions and will develop and enforce appropriate legislation and regulations. Private-sector activities will be conducted on this basis at level 3 and in turn will affect the quantities of goods and services produced at level 4 and the prices at which they are traded.

The dashed arrows in Figure 1 pointing from bottom to top indicate that the lower levels also provide feedback to the levels above. For example, at level 4, it might be assessed that a potential investment project would be financially viable only if a change were made to institutions at level 3 or above. This could be a change in tax regulations or legislation, resulting in a reduction of costs at level 4. Another feedback loop would arise if in the implementation of an approved project it became clear that its financial assessment did not take into account costs that materialize at level 
4 but was based on assumptions made about institutions at the higher levels. An example is the negative externalities associated with greenhouse gas (GHG) emissions. To an increasing number and variety of constituencies-insurance companies, those exposed to extreme weather conditions, and those whose health is being negatively affected, to name but a few-these emissions pose risks and increase costs at level 4. However, to internalize these negative externalities in the price of GHG-emitting energy resources requires institutional changes at all three levels, starting from the very top level, level 1 . For example, international climate change policy has been trying to achieve such changes by normatively defining the control of emissions as a 'public good' and developing relevant international agreements and subsequent national legislation, regulations, and contractual relations to transform energy systems so that much lower levels of GHG emissions are produced.

\section{Institutional change and how institutions evolve}

Related to the question about how institutions connect is the question about how institutions evolve across and within the different levels. Williamson conjectured that pressure from above was the most powerful and durable driver of institutional change. Institutional change that originates from the highest levels carries the greatest potential for transforming societies and their economies. ${ }^{9}$ Economic historians have pointed to institutional change to explain where and why major economic transformations have occurred (Tylecote 2015). More generally, theories of institutional change typically focus on explaining major transformations in the structures that underpin economic, political, and social exchanges (Immergut 2005). This suggests that transformational institutional change does not affect just one level, but all three levels of institutions, and that consistency and compatibility might be critical. The importance of consistency and compatability in institutional arrangments across the levels has been highlighted by research into the different institutional arrangements that underpin the similarities and differences in economic outcomes across industrialized countries (Hall and Soskice 2001).

\section{How to bring about positive institutional change}

A third gap centres around how to bring about positive institutional change. The effectiveness of a purposeful institutional change is likely to suffer when such a change results in an institution that is inconsistent and incompatable with other institutions at the level above or at the same level. For example, it may be very difficult to successfully implement an improved mining or petroeum law if its contents are at odds with strongly held beliefs or norms about resource property rights and/or with other laws and regulations that are important to other government agencies that may hold vested interests in maintaining the status quo. Thus, effective enforcement of changes to specific institutions of level 2 and level 3 often requires complementary institutional changes to be negotiated in relation to existing level 1 and level 2 institutions.

The history of economic transformations provides further insights. Such transformations have typically coincided with fundamental changes to rights granted and enforced at level 2, these being brought about by structural transformations that have altered the dynamics between socio-political constituencies and challenged the level 1 social order that backed the prevailing property rights regime. In the past, such structural changes have included technological breakthroughs and major

\footnotetext{
${ }^{9}$ See also Shirley (2008).
} 
demographic shifts. Looking forward, climate change and related policy-induced innovations are likely to drive a game change. ${ }^{10}$

\section{Bureaucracy and state capacity}

A further gap that Williamson identified is that relatively little attention had been paid to bureaucracy and state capacity. State capacity plays a critical role in connecting the often informal institutions of level 1 into formalized systems of government at level 2. It is through these that nation states and their public authorities actually exercise their monopoly over power, for example in providing basic public goods and services such as security and the rule of law. State capacity is also critical to how effective and inclusive the exercise of power is.

An observed gap in the 'good governance' agenda of the development community is attention to the question of how the institutions that allow nation states to accumulate and use power actually emerge, and under what conditions such power is used to support broad-based economic and social development (Andrews 2013). Fukuyama (2013) points out that the political processes by which objectives and goals are set also establish the administrative capability required to deliver on these. Thus, short-cutting those processes by prioritizing objectives and goals from elsewhere and downplaying the role of bureaucracy and state capacity-let alone going as far as dismantling (rather than improving) these in efforts to cut 'unnecessary red tape'-can be a serious risk, as the consequences will only become apparent later and rebuilding such capacity will take a long time.

Williamson concluded that economists had been rather ignorant about how institutions work and how they emerge. Owing to the complexity of the subject, the lowest-common-denominator view was simply that 'institutions matter'. Grindle (2010) concurs, with her observation that 'good governance' has provided a fig leaf-like 'technical' approach to escaping the dead-end into which market liberalism, with its tendency to ignore the role of institutions in market transactions, has pushed economists in the IMF, the World Bank, and other international organizations.

\subsection{Application to the extractive resources sector}

It is now time to apply Williamson's framework to the extractive resources sector, covering the four levels set out in Figure 1. This section approaches the application in reverse order, starting with level 4 and working up to level 1. The reason for the reversed order is that extractive companies usually approach their decisions - on whether or not to develop resources projectsfrom level 4, where commercial considerations are key.

\section{Level 4: Commercial decisions}

Level 4 captures the world of market analyses and resource producers' assessments of commercial opportunities and risks, where the institutions in place are assumed to be stable. At this level, resource developers run their project models, continuously updating their commercial evaluations on the basis of market analysis, and look at demand and supply, prices and costs. In principle, any perceived risks that relate to changes in institutions at level 3 and above are factored into the project economics as costs or via the discount rate. This results in higher perceived political risk, which in turn requires a higher expected rate of return.

\footnotetext{
${ }^{10}$ Viewed more negatively, global collective failure to deal with climate change impacts will also lead to a structural change in the world as we know it today.
} 
As extractive resources projects typically involve large-scale investments in immobile assets that are tied up for long periods, resource developers strive to lock in investment conditions with legal instruments that seek to make investments safer (Maniruzzaman 2008). Typically, these include level 3 institutions, such as investment contracts, payment guarantees, and stability clauses.

Where political risk is very high, it in effect turns into 'uncertainty', which means that no probability can be assigned to the occurrence of the feared risk events. Such uncertainty holds back investments in countries with histories of conflict. Alternatively, investors modify their projects in ways that seek protection. In the worst case, such 'protection' entails payments to potential 'predators' in government, or contending rebel groups, or both (Addison and Murshed 2005). ${ }^{11}$

\section{Level 3: Contracts and agreements}

Level 3 captures different types of contracts and agreements, including those between resource developers and the governments of producer countries as well as their state-owned extractive industry companies, where such exist. This level covers contracts and agreements with third parties. Resource developers typically involve their substantial legal teams and procurement services to negotiate and deliver on such contracts and arrangements.

There is a substantial body of sector-specific literature that focuses on the contractual relationship and the negotiations between resource developers and host governments and, where applicable, their state-owned petroleum and mining companies. This literature is too vast to cover here in any detail. ${ }^{12}$ It reflects the strong focus that prevails in the industry on companies' bilateral, negotiationdriven relationship with national governments. Far less thought is typically given to the relationships between a national government, its public authorities, and its citizens and how those relationships may affect the enforcement of contracts and agreements.

Level 3 also captures the contractual relationships between resource developers and third parties, including the companies from which the resource developers purchase goods and services and those to whom they sell their output. Again, there is a substantial body of literature dedicated to the structuring and negotiating of such contracts and agreements (see also the papers by Löf and Östensson (2017, forthcoming); and Östensson (2017, forthcoming). The focus is on balancing costs, safety of delivery, and efficiency in terms of timelines.

In addition, level 3 covers contracts and agreements that resource developers may negotiate directly with local communities. These can be a mandatory requirement or a means to address expectations, which, if unmet, pose socio-political risks (see Box 1 and the paper by Otto (2017) on the controversially viewed proposal to legislate community development agreements).

\section{Level 2: Property rights, political and administrative systems, sector legislation}

The sector-specific institutional environment of level 2 sets out who formally owns extractive resources and therefore who can issue licences to resource developers to explore and exploit such resources. Level 2 covers:

- Resource property rights, typically set out in host countries' constitutions. These rights clarify the primary ownership of resources and which of them can be licensed to resource

\footnotetext{
11 See also Melia (2015) and Snyder (2006) for political-economic models and empirical examples specifying such protection arrangements.

${ }^{12}$ For example, see Cameron (2010).
} 
developers. Legal traditions and historical trajectories play a key role in defining primary resource ownership. ${ }^{13}$

- Political and administrative systems, i.e. which government and public authorities develop policies, propose and approve laws, collect taxes and other public revenues, and administer the enforcement of laws, regulations, and public policies. For example, the institutional environment can be particularly complex in countries that are federations or comprise several decentralized states, regions, or provinces (e.g. Argentina, Australia, Brazil, Canada, Peru, Indonesia).

- Sector-specific and sector-relevant legal and regulatory regimes, which set out how primary resource rights can be allocated and what obligations come with these, such as domestic market obligations and local procurement and employment targets. Additional relevant legislation includes international investment regimes, on the basis of which companies negotiate the contractual arrangements that underpin their investments, sales, and export decisions at level 3.

- Various special fiscal institutions and measures that host countries have been advised to adopt as part of good sector governance reforms, such as legislation to establish stabilization and savings funds, or sovereign wealth funds.

The wider institutional environment of level 2 conditions the range and the quality of the public goods and services that nation states provide to their citizens and the private sector. This level not only affects the cost structure of the production inputs that resource developers and their supply chains need (e.g. human capital and infrastructure); it also affets the ability of the domestic private sector to leverage the resources sector to induce economic activities in other sectors.

In summary, a wide range of level 2 institutions shape the relationship between public authorities and resource developers and are critical for leveraging the potential development opportunities associated with extractive projects, as well as mitigating their negative impacts. It should come as no surprise now that the complexity of this level suggests that the four gaps in knowledge discussed in sub-section 3.2 are particularly relevant for level 2 (i.e. 'bow the levels connect, 'bow institutions evolve', 'enforcing positive institutional change', and 'the role of bureaucracy and state capacity').

Level 1: Norms, principles, customs

At level 1, sector-specific institutions include long-standing norms and principles, such as the historic principle of 'first come, first served' applied in the mining sector and the petroleum sector's 'law of capture..${ }^{14}$ In many countries these principles have become firmly and formally embedded in sector legal frameworks.

Level 1 institutions also include customary rights to resources, which are often not formally embedded in sector legal frameworks and may overlap or conflict with formal rights. Such rights include those of indigenous peoples and other traditional communities. Historically, indigenous peoples have often been disadvantaged, their lands being expropriated to make way for mining and other developments. Box 1 gives an example of how Australia has approached the formalization of such level 1 rights, by putting in place legislation at level 2, which has then affected levels 3 and 4.

\footnotetext{
13 See Scott (2008) for a comprehensive historical review of the evolution of resource property rights.

${ }^{14}$ See Daintith (2010) for a comprehensive historical account of the 'law of capture'.
} 
There has been a trend towards strengthening the rights of indigenous peoples through the establishment of international norms recognizing their existence and developing processes to give them a 'voice' in the decision-making process relating to the use of resources. These norms include Convention 169 (1989) of the International Labor Organization and the concept of Free, Prior and Informed Consent (FPIC) set out by the 2007 UN Declaration on the Rights of Indigenous Peoples.

\section{Box 1: Rights of indigenous peoples}

The customary rights of indigenous peoples, located at level 1, provide an illustrative example of how the four levels of Williamson's framework connect. These are rights held in common that have typically not been formalized and often overlap with the formalized rights of surface landowners and the owners of sub-surface resources, typically established at level 2.

When resource developers are licensed to explore and exploit extractive resources from underground, overlapping rights can cause tensions and conflicts. Different approaches have been tried to mitigate such tensions and conflicts by formalizing customary rights, thus bringing them down to levels 2 and 3 .

For example, the Australian government sought to address tensions and conflicts between the mining sector and Aboriginal communities by introducing the Native Title Act (1993), which sets out a process for formalizing these informal rights. It obliges resource developers to identify and confirm who the Aboriginal communities are that might lay claim to such rights within the geographical areas for which the resource developer holds licences, and how they might be affected. Once this has been established, through ethnographic and anthropological studies, the resource developer and the identified communities will negotiate indigenous land-use agreements (ILUAs), which provide the affected Aboriginal communities and their members with financial and other in-kind benefits.

In summary, the Native Title Act formalizes the customary rights of level 1 at level 2 and provides the basis for negotiating ILUAs at level 3. These in turn have an impact on project economics, i.e. resource developers' allocation of resources at level 4.

Additional international norms have emerged on identifying and minimizing negative impacts at the project level. These include the IFC Performance Standards on Environmental and Social Sustainability (IFC 2012) and the UN Guiding Principles on Business and Human Rights (United Nations 2011). Some international resource developers draw up their own corporate commitments, policies, and standards against these benchmarks.

Level 1 institutions can also be seen to include international norms on resource sector governance. For example, normative demand for more transparency has led to the development of respective level 2 institutions in the form of Chapter 10 of the EU Accounting Directive of 2013 and certain provisions in the US's Dodd-Frank Wall Street Reform and Consumer Protection Act. ${ }^{15}$

Figure 2 applies Williamson's 'economics of institutions' to the resources sector. The intention is to provide a reference against which to compare the topics covered by other papers published under Extractives for Development project and to prompt readers to think about how these papers relate to the four gaps in knowledge discussed in sub-section 3.1. The next sub-section applies the gaps to the extractive resources sector.

${ }^{15}$ See David-Barrett and Okamura (2016) for an assessment of the transparency norm from an international reputation perspective. 
Figure 2: Williamson's 'economics of institutions' applied to the resources sector

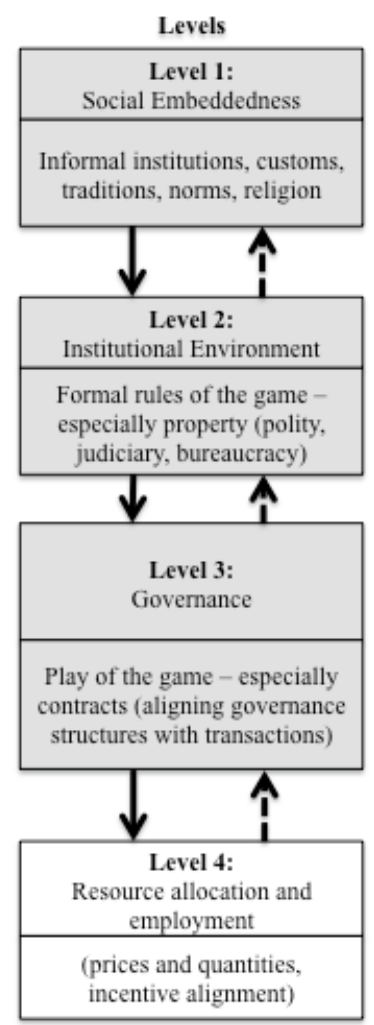

Sector specific examples

- Sector norms and principles such as 'First come, first serve', 'Law of capture'

- Informal rights to, and expectations in relation to resources

International norms and standards

Who owns extractive resources and can issue licenses for exploration and production:

- Constitutional provisions on primary resource ownership

- Political and administrative systems - levels of government and public authorities involved

- Sector legal and regulatory frameworks, special fiscal institutions

- Bureaucracy and state capacity to provide wider public goods and services, affecting how the sector interacts with other sectors and society more generally.

Contracts and agreements, between:
- Resource developers and governments, and where applicable state-owned
companies - framed as bilateral negotiations aimed at securing assumptions make
for 'project economics'
- Resource developers and their suppliers and their customers - balancing costs,
safety and meeting timelines
mesource developers and other third parties (e.g. communities) - mandatory or to
Commercial decisions that pose socio-political risks
Project economics, factoring in all costs including, where possible, those related to
political and social risks

Source: Author's figure.

\subsection{Gaps in knowledge, applied to the extractive resources sector}

At this stage, it is worth recalling that, despite the consensus that 'institutions matter', there is no straightforward answer to the question what are institutions? Section 3.2 highlighted four gaps in knowledge that Williamson identified in 2000, when he reviewed the progress scholars had made on understanding the role of institutions. This section relates these four gaps specifically to the extractive resources sector.

\section{How do institutions connect across the levels?}

Institutional reforms targeting the extractive resources sector have often focused on specific level 2 and level 3 institutions, such as revising the sector's legal and regulatory frameworks and renegotiating contracts and agreements. More recently, however, there has been a shift towards greater recognition of the political settlements underpinning the societies and economies of resource-producing developing countries (Melia 2015). The aim of this shift has been to better understand variations in the political economy of extractive institutions across (mostly) SubSaharan African resource-producing countries. ${ }^{16}$

Behind these variations lie different institutional legacies that affect the connections between the levels. For example, in countries where the legal tradition is based on Common Law, decisions

\footnotetext{
${ }^{16}$ Melia (2015) has drawn on three strands of structural-institutional analysis to focus on how social orders established at level 1 affect the formal rules of the game at level 2 across various Sub-Saharan African countries. Similarly, Snyder (2006) and Jones Luong and Weinthal (2010) have developed theories on the political economy of resources based on comparative case analyses.
} 
made by judges pertaining to disputes at level 3 are incorporated into level 2. For example, Daintith (2010) describes how, in the early phases of petroleum development, the decisions of US judges acting under Common Law set off a path dependency that shaped subsequent court decisions. This enticed private landowners to engage in competitive drilling, which in turn led to the rapid expansion of fossil fuels as a major source of energy in the US, with far-reaching consequences well beyond the United States. ${ }^{17}$ Meanwhile, in countries with civil law traditions, the law-making role is reserved for the legislature and level 2 statutes are the primary source of legislation.

\section{Institutional change: how do institutions evolve?}

Williamson conjectured that pressure from above is the most powerful and durable driver of institutional change across the levels. In the extractive resources sector the trend has been towards establishing new international norms and standards at level 1 with the intention that their influence percolates downward from there. In some cases, these norms and standards have evoked new level 2 legislation and regulations, in both producer countries and home countries. An example is Chapter 10 of the EU Accounting Directive, requiring all EU member states to put in place regulations requiring resource developers to publish details of resources revenues paid to host governments. ${ }^{18}$ In other cases, normatively developed initiatives have skipped level 2 and have targeted directly the corporate practices of international resource developers at level 3 . For example, this applies to the above-mentioned cases of the IFC Performance Standards on Environmental and Social Sustainability (IFC 2012) and the UN Guiding Principles on Business and Human Rights (United Nations 2011), which also apply to the extractives sector.

A question left unanswered is whether, or to what extent, such types of level 1 institution have been able to catalyse positive changes to a wider range of level 2 institutions in the producer countries themselves. It may be suggested that the transformation of social and economic structures in producer countries cannot be brought about solely by improving corporate social performance, nor by paying narrow attention to, for example, the subject of revenue transparency. The papers by Lahn and Stevens (2017) and by Dietsche (2017, forthcoming) allude to this suggestion in relation to diversifying economies away from dependence on extractive resources.

\section{Bringing about positive institutional change: where are the levers?}

Section 3.2 argued that the challenges for bringing about positive institutional change are (a) to make level 1 and level 2 institutions connect with each other and (b) to make level 2 institutions complement and reinforce each other.

Institutional change cannot be limited to sector-specific institutions if the sector is to contribute positively to wider economic and social development. The latter requires more far-reaching changes to the level 2 institutions that underpin the delivery of public goods and services. The reason is quite simple: there is no guarantee that transparency on the revenues that countries receive from the primary resource developers will lead to changes in how spending priorities are decided upon and how the spending is translated into concrete public goods and services that increase productivity in other economic sectors. For other economic sectors to thrive alongside the extractive resources sector requires not only a broadly conducive business environment but also tacit knowledge relevant to the production of non-extractive goods and services. Such

\footnotetext{
${ }^{17}$ For a summary, see Dietsche (2013). Scott (2008) provides a historical account of the evolution of resource property rights with a focus on mining and other natural resources (e.g. fishing, forestry, grazing, hunting).

18 See http://eur-lex.europa.eu/legal-content/EN/TXT/PDF/?uri=CELEX:32013L0034\&from=EN (accessed 8 July 2016). See Dietsche (2015) for a summary of this reporting requirement.
} 
knowledge is built by gaining experience over time. Thus, improving governance is not a simple technocratic task, though it is often presented as such. Potential levers for positive institutional change are bound to be context-specific and not independent of the ability of relevant stakeholders to forge alliances that can support more comprehensive institutional change across level 2 institutions. For example, North et al. (2006) developed a conceptual framework spelling out the 'doorstep conditions' and subsequent 'transition steps' that have allowed some countries to transform their social order in such a way as to generate institutions that underpin substantial productivity increases (see Section 4.2).

What role does state capacity play?

Sate capacity connects the (often informal) institutions of level 1 with the (usually more formal) institutions of levels 2 and 3 . The structural transformation of resource-dependent economies requires coordinated planning and interventions across the wider public sector. North et al. (2006) allude to the institutionalized provision of public goods and services and its importance for broadbased increases in productivity, including the funding mechanisms required to pay for such provision (e.g. taxation).

This contrasts with alternative suggestions for remedies for poor outcomes in resource-rich countries that underplay the importance of state capacity, such as the suggestion to support barter deals, whereby resources are exchanged for public infrastructure rather than resources revenues being disbursed into government coffers, ${ }^{19}$ or the idea of disbursing resources revenues directly to citizens in the form of cash transfers, as tried out in Mongolia and Alaska. One could argue that this type of proposition is a means of circumventing the challenge of weak state capacity and the difficult task of building (or re-building) it.

The depth of the challenge of building state capacity is highlighted by recent research into governance in areas of 'limited statehood' and so-called 'ungoverned spaces' (Mingst 2013). Mingst starts with the observation that state sovereignty does not apply to about 80 per cent of the world's population. This fact stands in stark contrast to the assumption of state sovereignty that underpins the objective of achieving 'good governance'. By looking at alternative authority exercised in contested spaces and what economic activities this supports, Mingst confirms the importance of state capacity and the institutionalization of public goods and services provision for achieving broad-based developmental outcomes on the back of extractive resources exploitation. Taking the thinking a step further, it forces the 'good governance' agenda to reflect upon what it has contributed to building state capacity.

\section{Discussion}

Two political-economy issues merit further attention: the first concerns the question whether institutions are considered an independent or a dependent variable; the second concerns the transformation of social order.

\subsection{Independent or dependent variable?}

The question whether institutions are considered an independent or a dependent variable is an important one, because knowing that institutions matter (i.e. are an independent variable) is not

${ }^{19}$ Collier and others cited in Melia (2015: 49). 
the same as understanding how they evolve and how to actively bring about positive institutional change (i.e. regarding them as a dependent variable). Even if a particular institutional feature has served as a variable to successfully explain variance in outcomes across resource-dependent economies, it does not follow automatically that this variable is suitable for policy interventions. It also does not say much about how specific institutions work in relation to other institutions across and also within each of the three levels. Stevens et al. (2015) refer to the example of Norway and its Petroleum Development Fund as a model that other countries have been advised to consider for the 'good governance' of the sector. Somewhat cynically, they state that to make the model work elsewhere, the advice would also have to be to start with 4.5 million Norwegians!

When institutions are considered an input variable, it is assumed that they can constrain the behaviour of powerful political elites. But this leaves open the fundamental question as to how these very same elites can be convinced to develop or adopt such institutions in the first place. Yet, the push for such institutions by elites is vital for the institutionalized provision of public goods and services. In other words, it takes considerably more than international advocacy and political pressure to convince those exercising authority on the ground that it could be in their interest to use their monopoly over power and public resources to provide institutions that benefit not just themselves, but also others. An additional condition is that they must first hold such a monopoly and be able to raise sufficient public resources.

The consequence of this line of argument is that it takes a conscious shift in mindset from a view that institutions are an input for achieving a desired outcome to one where institutions are seen as the outcome of socio-political processes. The analytical usefulness of the concept of 'institutions' lies in their serving as a bridge to overcome the fundamental problem of structure versus agency: agency-focused theories hold individuals responsible for economic, political, and social outcomes, while structural explanations subject the actions of individuals to more hard-wired conditions. ${ }^{20}$ Thus, drawing on the concept of institutions is useful only in order to identify how and when collective agency makes it to the point of pushing the door open for structural transformation.

\subsection{Transforming social order}

The second issue concerns the transformation of social order in such a way that public authorities provide institutions that transcend personal relationships and broaden access to economic opportunities. This issue is about connecting level 1 and level 2 institutions: in order to establish and enforce level 2 institutions in line with level 1 institutions, public authorities must, first, hold a monopoly over power and, second, use this power to institutionalize the provision of public goods and services. Nowhere is the absence of such a monopoly over power more apparent than in states where civil wars erupt.

In modern nation states, elected governments and their public authorities are believed to hold this power legitimately and are trusted to exercise it fairly and transparently. Using this power, they provide and enforce institutions as a 'public good', thus serving everybody residing with the territorial boundaries of the nation state. Perhaps the most important public good is the nondiscriminatory enforcement of the 'rule of law' by the public authorities overseen by an elected government. However, it is worth remembering that with the territory of holding the monopoly over power comes the ability to threaten and use force to coerce individuals to behave in certain ways.

${ }^{20}$ For a debate on this issue, see Hay and Wincott (1998). 
Enforcing level 2 institutions also requires sufficient fiscal resources to fund enforcement mechanisms. Taxation is an important aspect of these. Another aspect is the cost of enforcement, which depends on level 2 institutions being underpinned by respective institutions at level 1. For example, compliance is most efficiently achieved if individuals internalize norms, principles, and ideas that guide their behaviour and decisions, as opposed to having to be coerced to comply. From this derives the positive role of public authorities in addressing the issues underlying conflicts and tensions around the exploitation of extractive resources. Positively, this is achieved through political processes that establish a consensus on balancing the costs and benefits associated with such exploitation. Negatively, it is achieved through coercing and oppressing those who must bear the costs imposed on them by the benefits that others are enjoying.

The political economy framework presented by North et al. (2006) describes the complexity of the historical processes that have allowed more advanced countries to transition to social orders that have supported broad-based economic and social development. The countries achieving such transitions early on were Britain, France, and the United States, followed by other European, and a few other, countries. These countries have evolved to grant their citizens rights and provide public goods and services that have opened up access to economic opportunities. ${ }^{21}$ The work of North et al. (2006) serves as a stark reminder of how exceptional (and potentially delicate) such a social order is.

Melia (2015) has used a part of this particular framework to describe how Equatorial Guinea, South Sudan, and Chad have become stuck with social orders that limit access to economic opportunities to elites. In a similar fashion, he has drawn upon two additional political-economic frameworks describing the relationships and alignments between key social constituencies to reflect upon the particular social orders that underpin six other resource economies. Specifically, for the cases of Mozambique, Angola, and Nigeria he uses the Politics of Industrial Policy framework of Whitfield et al. (2015), and for the cases of Peru, Ghana, and Kenya, the Political Settlement Theory of Khan (2010).

Contrary to the assumption implicit in the 'good governance' agenda, none of these three frameworks assumes that countries are all striving towards some imagined uniform social order where sovereign states 'fully' govern their territories. Rather, each framework highlights that the exercise of statehood is, in some form or another, compromised and/or power is shared between contending parties. However, the challenge with Melia's approach is that he can only explain the evolution and current status quo of these three sets of countries. He does not go a step further to identify the collective agency that would be required to move each of these countries towards improving their currently unfavourable social orders. ${ }^{22}$

In contrast to Melia's focus on explaining the respective countries' status quo, North et al. (2006) identified three 'doorstep conditions' that precede and lay the foundation for the transition from a social order that limits access to one that provides open access to economic opportunities and institutionalizes the provision of public goods and services. There is not space within this paper to delve into the historical analysis on which these scholars' propositions are built, but it is useful to

\footnotetext{
${ }^{21}$ North et al. (2006) acknowledge that the Netherlands and Switzerland could also be included in the group of early transition countries, but their work does not include them.

${ }^{22}$ To be fair, Melia (2015) discusses 'remedies', referring to macroeconomic assistance, transparency and accountability initiatives, resources for infrastructure deals, and direct cash transfers, and focusing on thematic fields for bilateral development engagements on strategic planning, employment creation, local economic development, and cooperation with extractives sector companies.
} 
briefly mention the three conditions: initial 'rule of law for elites'; 'perpetually lived organizations in the public and private sphere'; and 'consolidated control of the military':

- The first condition refers to the formalization of procedures for arbitration and mediation backed by the establishment of property rights and a judicial system.

- The second condition refers to organizations that outlive the individual members who created them and become 'legal persons' bearing rights and duties.

These two conditions create the space for more impersonal relationships among the elites, while at the same time constraining absolute power.

- Finally, the third condition is the legitimization of the use of violence, as opposed to its arbitrary use.

North et al. (2006) argue that when these foundations are in place, elites are more likely to find a common interest in transforming their privileges into impersonal rights shared among them. They can then convert these into rights that are granted to citizens more broadly.

In summary, transforming social order takes time, and this leads to two conclusions:

- Sustainable outcomes, which balance the benefits associated with granting rights to resources with the costs of producing these, are unlikely to be achieved through the rapid development of one extractive project (see Stevens et al. (2015)'s discussion on the pacing of extractive resources development and the paper by Lahn and Stevens (2017).

- Such outcomes are more likely to be achieved in countries where there are ample resources for consecutive developments, providing a longer time span for elites to work towards transforming social order. At the same time, these countries also face a greater risk of entrenching poor social orders to the benefit of those elites, thus undermining the achievement of doorstep conditions and the subsequent structural transformation.

Moving beyond personal networks of rent redistribution is critical for balancing the benefits associated with granting rights to resources with the costs of producing these. The historical literature suggests that whether or not nation states do so has to do with how their political and economic elites align between themselves and how this alignment affects the non-elites. As the institutions of enforcement at level 2 are conditioned by the social order among elites and their relationship to non-elites, positive institutional change for better outcomes requires the transformation of existing social orders.

While the direction of travel may be clear, there is no generic template showing how to get to the destination of a social order that opens access to economic opportunities. The work of North et al. (2006) provides a conceptual framework pointing to the landmarks that pathfinders should look out for on the road to achieving the transformation of social order. However, its drawback is that it rather underplays the role of those who collectively prepare and walk those paths, as Bates (2010) noted. Arguably, resource developers and third parties are already claiming that their contributions are supporting positive change-third parties in particular claiming to support positive collective action.

Drawing again on Williamson's 'economics of institutions', Figure 3 provides a reference point for assessing whether and how these parties contribute to (a) the connections between levels 1 and 2, (b) the importance of state capacity at level 2, and (c) the consistency and complementarity of institutional arrangements within each level, and across the three levels. On the left-hand side, Figure 3 repeats the four levels of Williamson's 'economics of institutions' introduced in Figure 1 
and applied to the resources sector in Figure 2. On the right, it sets out three modes through which these parties make a contribution, as explained below.

Figure 3: Contributions by resource developers and third parties to the 'economics of institutions'
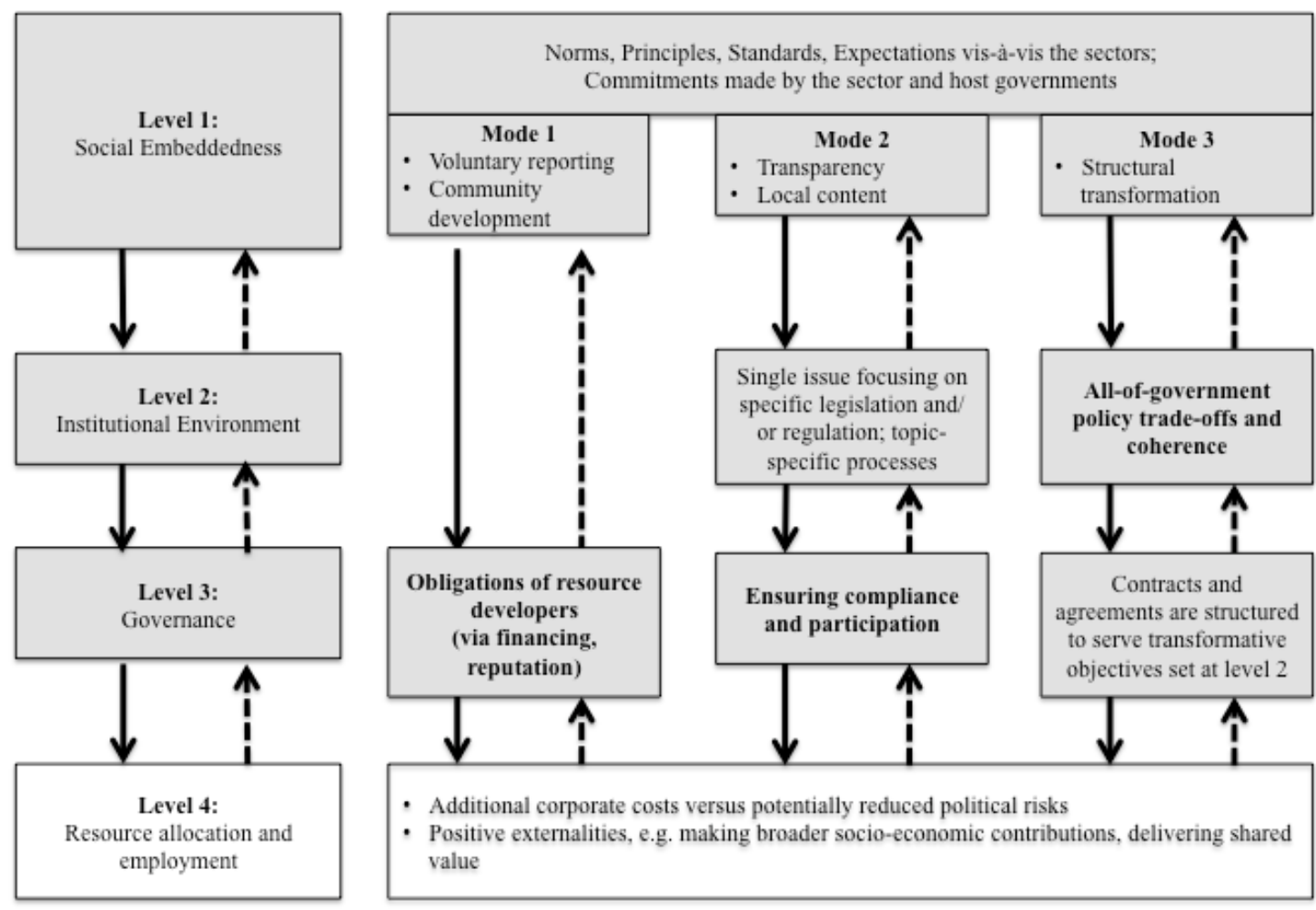

Source: Author's figure.

\section{Mode 1: Voluntary reporting against international standards and social investments in community development}

The first mode captures third parties' advocacy for, and resource developers' adherence to, 'dono-harm' environmental and social performance standards, reporting requirements, and social investments in community development. These contributions may take notice of level 2 institutions-for example, as part of social risk and impact assessments-but there is rarely the intention that such contributions should make any explicit difference to the host countries' level 2 institutions (although they are sometimes talked about as if they contributed to sustainable economic development at the country level). Arguably, in areas of limited statehood and so-called 'ungoverned spaces', mode 1 typically represents the only practical course of action to deliver positive outcomes at the local and community level.

\section{Mode 2: Transparency and local content}

The second mode captures contributions that focus on particular, sector-specific issues and are thought to improve country-level outcomes, along the lines of emphasizing 'good institutions' and 'good governance' as an independent variable. Emphasis is often placed on particular legislation or regulation or specific processes that will bring about improvements in the particular issue, with a focus on compliance and participation in single-issue processes. One example is specific transparency legislation introduced at level 2 of both the host country and home country-for example, the above-mentioned Chapter 10 of the EU Accounting Directive. Another example is the subject of 'local content', i.e. procurement of goods and services in the country (see Dietsche 2017, forthcoming). 


\section{Mode 3: Structural transformation}

Mode 3 views the extractive resources sector as integral to a country's economy and society and homes in on the contributions the sector can make towards structurally transforming a country's economy in such a way that it becomes more diversified. The presumption is that the sector can, on balance, make positive contributions if the country's social order evolves towards providing open access to economic opportunities and institutionalizes the provision of public goods and services. This mode relates to the doorstep conditions and elite interest re-alignments highlighted by North et al. (2006).. Arguably, mode 3 holds the most promise for bringing about positive institutional change for better outcomes at the country level.

In summary, there is still a lot to be learned and thought about how a positive political economy of elite realignment and collective action required for pushing towards structural transformation can be supported by resource developers and third parties.

\section{Conclusions}

This paper has argued that the debate on the political economy of extractive resources was initiated by the challenge of explaining the dismal performance of many resource-rich countries. 'Bad' resource sector governance was one such an explanation, associated with those managing the sector. Consequently, it was argued that institutional constraints are needed to prevent selfinterested rational individuals from using resource rents for personal gain. Those looking towards institutional analyses to provide guidance as to how to improve the governance of the sector often focused on particular types of sector-specific institution. Much hope has been placed on transparency as a means to achieve greater accountability of outcomes.

This paper has argued that, erroneously, less emphasis has been put on understanding how and why those holding power might create institutions that support positive outcomes. The paper has drawn on the general criticism of the 'governance' concept to review the literature on the political economy of extractive resources and institutions.

- Section 2 juxtaposed agency-focused explanations with structural explanations to identify their different outlooks on the importance of 'time' and on 'institutional choices' versus 'institutional change'.

- Section 3 went on to pose the questions 'what in fact are institutions?', 'what gaps in knowledge remain?', and 'how might positive institutional change be brought about?'. The insights gained from the broader social science discussion were then applied to the extractive resources sector to identify the specific gaps in knowledge that apply to the extractives-led development agenda. These included the scant recognition of the need for broader consistency and complementarity within and across institutional arrangements at different levels, and in particular those located at level 2. Another gap identified was the lack of attention that economists have paid to state capacity and a social order in which political-economic elites limit the institutionalized provision of public goods and services supporting broad-based increases in productivity (and by implication economic diversification).

- Finally, Section 4 homed in on two critical issues: first, the requirement for a conscious shift in mindset from viewing institutions as an independent variable to seeing them as the outcome of socio-political processes; second, on the challenge of positive institutional change, the transformation of social orders in such a way as to guarantee the institutionalized provision of public goods and services supporting broad-based increases 
in productivity. Drawing on the political economic framework presented by North et al. (2006) and its recent application to the extractive resources sector by Melia (2015), Section 4 highlighted the doorstep conditions that this work has identified for positive transformation. It concluded that, while the direction of travel is becoming clear, there is no generic template that can be applied in order to arrive at the destination of a social order that opens access to economic opportunities. Finally, the paper offered a model for assessing how resource developers and third parties contribute to the gaps in knowledge.

\section{References}

Acemoglu, D., S. Johnson, and J.A. Robinson (2001). 'The Colonial Origins of Comparative Development: An Empirical Investigation’. American Economic Review, 91(5): 1369-401.

Addison, T., and S. Mansoob Murshed (2005). 'Post-conflict Reconstruction in Africa: Some Analytical Issues'. In A.K. Fosu and P. Collier (eds), Post-conflict Economies in Africa. Basingstoke: Palgrave Macmillan.

Ahrens, J. (2000). 'Toward a Post-Washington Consensus: The Importance of Governance Structures in Less Developed Countries and Economies in 'Transition'. Journal of Institutional Innovation, Development and Transition, 4: 78-96.

Ahrens, J. (2002). Governance and Economic Development: A Comparative Institutional Approach. Cheltenham: Edward Elgar.

Andrews, M. (2013). The Limits of Institutional Reform in Development. Changing Rules for Realistic Solutions. Cambridge University Press.

Arndt, C., and C. Oman (2006). Uses and Abuses of Governance Indicators. Paris: Development Centre Studies, Organisation for Economic Cooperation and Development (OECD).

Auty, R.M. (2001). 'The Political Economy of Resource-driven Growth'. European Economic Review, 45: 839-46.

Auty, R.M., and A.H. Gelb (2001). 'The Political Economy of Resource-abundant States'. In R.M. Auty (ed.), Resource Abundance and Economic Development. UNU-WIDER Studies in Development Economics. Oxford University Press.

Barma, N., K. Kaiser, T. Minh Le, and L. Viñuela (2012). Rents to Riches. The Political Economy of Natural Resource-led Development. Washington, DC: The World Bank.

Bates, R.H. (2010). 'A Review of Douglass C. North, John Joseph Wallis, and Barry R. Weingast's "Violence and Social Orders: A Conceptual Framework for Interpreting Recorded Human History". Journal of Economic Literature, 48(3): 752-56.

Benner, T., and R. Soares de Oliveira, with F. Kalinke (2010). 'The Good/Bad Nexus in Global Energy Governance'. In A. Goldthau and Jan Martin Witte (eds), Global Energy Governance. The New Rules of the Game. Washington, DC/Berlin: Brookings Institution Press/Global Public Policy Institute.

Bräutigam, D., O.-H. Fjeldstad, and M. Moore (eds) (2008). Taxation and State Building in Developing Countries: Capacity and Consent. Cambridge University Press.

Brousseau, E., and J.-M. Glachant (eds) (2008). New Institutional Economics. A Guidebook. Cambridge University Press. 
Brunnschweiler, C.N., and E.H. Bulte (2008). 'The Resource Curse Revisited and Revised: A Tale of Paradoxes and Red Herrings'. Journal of Environmental Economics and Management, 55(3): 24864. DOI: 10.1016/j.jeem.2007.08.004.

Cameron, P.D. (2010). International Energy Investment Law. The Pursuit of Stability. Oxford University Press.

Collier, P., and B. Goederis (2007). 'Commodity Prices, Growth, and the Natural Resource Curse: Reconciling a Conundrum'. Department of Economics, University of Oxford (preliminary draft).

Collier, P., and A. Hoeffler (2004). 'Greed and Grievance in Civil War'. Oxford Economic Papers, 54: 563-95.

Congleton, R.D., A.L. Hillman, and K.A. Konrad (2008). 'Forty Years of Research on Rent Seeking: An Overview.' In R.D. Congleton, A.L. Hillman, and K.A. Konrad (eds), Forty Years of Research on Rent Seeking 1. Theory and Rent Seeking. Berlin: Springer.

Daintith, T. (2010). Finders Keepers? How the Law of Capture Shaped the World Oil Industry. Resources For the Future Press/Earthscan.

David-Barrett, E., and K. Okamura (2016). 'Norm Diffusion and Reputation: The Rise of the Extractive Industry Transparency Initiative'. Governance: An International Journal of Policy, Administration and Institutions, 29(2): 227-46.

Davis, G.A., and A.L. Vásquez Cordano (2012). 'The Fate of the Poor in Growing Mineral and Energy Economies'. Resources Policy, 38(2): 138-51.

Dietsche, E. (2003). The Political Economy of Policy Decisions: Why Good Technical Reform Designs Don't Always Work, A Literature Review. Oxford Policy Institute.

Dietsche, E. (2007). 'Why the Quality of Institutions Is Not a Cure for the "Resource Curse"'. The Journal of Energy and Development, 32(2): 262-82.

Dietsche, E. (2013). 'Sector Legal Frameworks and Resource Property Rights'. In R. Dannreuther, and W. Ostrowski (eds), Global Resources. Conflict and Cooperation. Basingstoke: Palgrave Macmillan.

Dietsche, E. (2014). "Good Governance” of the Extractive Resources Sectors: A Critical Analysis'. PhD Thesis. University of Dundee.

Dietsche, E. (2015). 'Tax Transparency in the Energy Sector'. Oil, Gas \& Energy Law, 4. Available at: www.ogel.org/article.asp?key=3567 (accessed 16 January 2017).

Dietsche, E. (2017, forthcoming). 'New Industrial Policy and the Extractive Industries'. WIDER Working Paper 2017/xxx. Helsinki: UNU-WIDER.

DiJohn, J. (2007). 'The Political Economy of Taxation and Tax Reform in Developing Countries'. In H.-J. Chang (ed.), Institutional Change and Economic Development. London: Anthem Press and UNU Press.

Easterly, W., J. Ritzen, and M. Woolcock (2006). 'Social Cohesion, Institutions, and Growth'. Economics \& Politics, 18: 103-20.

Eifert, B., A. Gelb, and N.B. Tallroth (2003). 'The Political Economy of Fiscal Policy and Economic Management in Oil-exporting Countries', In J.M. Davis, R. Ossowski, and A. Fedelino (eds), Fiscal Policy Formulation and Implementation in Oil-producing Countries. Washington, DC: International Monetary Fund.

Fukuyama, F. (2013). 'What is Governance?' Governance: An International Journal of Policy, Administration, and Institutions, 23(3): 347-68. 
Gamble, C., J. Gowlett, and R. Dunbar (2014). Tbinking Big. How the Evolution of Social Life Shaped the Human Mind. London: Thames and Hudson.

Gelb, A. (1986). 'Adjustment to Windfall Gains: A Comparative Analysis of Oil-exporting Countries.' In J.P. Neary and S. van Wijnbergen (eds), Natural Resources and the Macroeconomy. Oxford: Basil Blackwell.

Granovetter, M. (1985). 'Economic Action and Social Structure: The Problem of Embeddedness'. American Journal of Sociology, 91(3): 481-510.

Grindle, M. (2010). 'Good Governance. The Inflation of an Idea'. Faculty Research Working Paper Series, 10-023. Harvard Kennedy School.

Gisselquist, R. (2012). Good Governance as a Concept, and Why this Matters for Development Policy. Working Paper 2012/30. Helsinki: UNU-WIDER.

Haber, S., and V. Menaldo (2011). 'Do Natural Resources Fuel Authoritarianism? A Reappraisal of the Resource Curse'. American Political Science Review, 105(1): 1-26.

Hall, P.A., and R.C.R. Taylor (1996). 'Political Science and the Three New Institutionalisms'. Political Studies, 31: 1-23.

Hall, P.A., and D. Soskice (2001). Varieties of Capitalism: The Institutional Foundations of Comparative Advantage. Oxford University Press.

Hay, C., and D. Wincott (1998). 'Structure, Agency and Historical Institutionalism'. Political Studies, 46: 951-57.

Hodler, R. (2004). 'The Curse of Natural Resources in Fractionalized Countries'. Diskussionsschriften 04-04. Universitaet Bern, Volkswirtschaftliches Institut.

Humphreys, M. (2005). 'Natural Resources, Conflict and Conflict Resolution: Uncovering the Mechanisms'. Journal of Conflict Resolution, 49(4): 508-37.

Humphreys, M., and M.E. Sandbu (2007). 'The Political Economy of Natural Resource Funds'. In M. Humphreys, J.D. Sachs, and J.E. Stiglitz (eds), Escaping the Resource Curse. New York: Columbia University Press.Hyden, G., J. Court, and K. Mease (2004). Making Sense of Governance Empirical Evidence from 16 Developing Countries. Boulder/London: Lynne Rienner.

IFC (2003). Striking a Better Balance. The Final Report of the Extractive Industry Review, Volume 1. The World Bank Group and Extractive Industries. December.

IFC (2012). Performance Standards on Environmental and Social Sustainability. Washington, DC: International Finance Corporation/World Bank Group.

Immergut, E. (2005). 'Historical Institutionalisms in Political Science and the Problem of Change'. In A. Wimmer and R. Kössler (eds), Understanding Change: Models, Methodologies, and Metaphors. Basingstoke: Palgrave Macmillan.

Isham, J., M. Woolcock, L. Pritchett, and G. Busby (2005). 'The Varieties of Resource Experiences: How Natural Resource Export Structures Affect the Political Economy of Economic Growth'. World Bank Economic Review, 19(2): 141-74.

Jenson, N., and L. Wantchekon (2004). 'Resource Wealth and Political Regimes in Africa'. Comparative Political Studies, 37(7): 816-41.

Jones Luong, P., and E. Weinthal (2010). Oil Is Not a Curse: Ownership Structure and Institutions in Soviet Successor States. Cambridge University Press. 
Khan, M. (2010). Political Settlements and the Governance of Growth-enhancing Institutions. Research Paper Series on Governance for Growth. School of Oriental and African Studies, University of London.

Koelble, T.A. (1995). 'The New Institutionalism in Political Science and Sociology'. Review Article. Comparative Politics, 27(2): 231-43.

Lahn, G., and P. Stevens (2017). 'The Curse of the One-size-fits-all Fix: Re-evaluating What We Know about Extractives and Economic Development'. WIDER Working Paper 2017/21. Helsinki: UNU-WIDER.

Löf, A., and O. Östensson (2017, forthcoming). 'Downstream Activities: The Possibilities and The Realities'. WIDER Working Paper 2017/xxx. Helsinki: UNU-WIDER.

Maniruzzaman, (Munir) A.F. (2008). 'The Pursuit of Stability in International Energy Investment Contracts: A Critical Appraisal of Emerging Trends'. Journal of World Energy Law \& Business, 1(1): 121-57.

Mehlum, H., K. Moene, and R. Torvik (2006a). 'Institutions and the Resource Curse'. The Economic Journal, 116(1): 1-20.

Mehlum, H., K. Moene, and R. Torvik (2006b). ‘Cursed by Resources or Institutions?’ The World Economy, 29(8): 1117-38.

Melia, E. (2015). 'The Political Economy of Extractive Resources'. GIZ Working Paper. October.

Mingst, K.A. (2013). 'Alternative Governance in Spaces and Territories. Book Review Essay'. International Studies Review, 13: 285-88.

Mkandawire, T. (2012). 'Institutional Monocropping and Monotasking in Africa'. In A. Noman, K. Botchwey, H. Stein, and J.E. Stiglitz (eds), Good Growth and Governance in Africa. Rethinking Development Strategies. Oxford University Press.

Moore, M. (2004). 'Revenues, State Formation, and the Quality of Governance in Developing Countries'. International Political Science Review, 25(3): 297-319.

North, D.C. (1990). Institutions, Institutional Change and Economic Performance. Cambridge University Press.

North D.C., J.J. Wallis, and B.R. Weingast (2006). Violence and Social Orders. A Conceptual Framework for Interpreting Recorded Human History. Cambridge University Press.

Opper, S. (2008). 'New Institutional Economics and its Application on Transition and Developing Economies'. In E. Brousseau, and J.-M. Glachant (eds), New Institutional Economics. A Guidebook. Cambridge University Press.

Otto, J. (2017). 'Legislating for Community Development Agreements'. WIDER Working Paper WP2017/xxx. Helsinki: UNU-WIDER.

Östensson, O. (2017). 'Local Content, Supply Chains and Shared Infrastructure'. WIDER Working Paper WP2017-xxx. Helsinki: UNU-WIDER.

Ostrowski, W. (2013). 'The Political Economy of Global Resources'. In R. Dannreuther, and W. Ostrowski (eds), Global Resources. Conflict and Cooperation. Basingstoke: Palgrave Macmillan.

Perälä, M. (2003). Persistence of Underdevelopment: Does the Type of Natural Resource Endowment Matter? Discussion Paper 2003/37. Helsinki: UNU-WIDER.

Pinto, B. (1987). 'Nigeria During and After the Oil Boom. A Policy Comparison with Indonesia'. The World Bank Economic Review, 3: 419-45. 
Polanyi, K. (1977 [1944]). The Great Transformation. Politische und ökonomische Ursprünge von Gesellschaften und Wirtschaftssystemen. Frankfurt: Suhrkamp Taschenbuch Wissenschaft.

Robinson, J.A., R. Torvik, and T. Verdier (2006). 'Political Foundations of the Resource Curse'. Journal of Development Economics, 79: 447-68.

Ross, M. (1999). 'The Political Economy of the Resource Curse'. World Politics, 51: 297-322.

Ross, M. (2004a). 'How do Natural Resources Influence Civil War: Evidence from 13 Cases'. International Organization, 58(1): 35-68.

Ross, M. (2004b). 'What Do We Know about Natural Resources and Civil War?'. Journal of Peace Research, 41: 337-56.

Ross, M. (2007). 'How Mineral-rich States can Reduce Inequality'. In M. Humphreys, J.D. Sachs, and J.E. Stiglitz (eds), Escaping the Resource Curse. New York: Columbia University Press.

Rosser, A. (2006a). The Political Economy of the Resource Curse: A Literature Survey. Working Paper 268, Institute of Development Studies (IDS), University of Sussex, Brighton. April.

Rosser, A. (2006b). 'Escaping the Resource Curse: Review Essay'. New Political Economy, 11(4): 55770.

Sachs, J.D., and A.M. Warner (1995). Natural Resource Abundance and Economic Growth. Working Paper 5398, Cambridge, MA: NBER.

Scott, A. (2008). The Evolution of Resource Property Rights. Oxford University Press.

Shirley, M.M. (2008). Institutions and Development. Cheltenham: Edward Elgar Publishing.

Snyder, R. (2006). 'Does Lootable Wealth Breed Disorder? A Political Economy of Extraction Framework'. Comparative Political Studies, 39: 943-68.

Stevens, P., and E. Dietsche (2008). 'Resource Curse: An Analysis of Causes, Experiences and Possible Ways Forward'. Energy Policy, 36: 56-65.

Stevens, P., G. Lahn, and J. Kooroshy (2015). 'The Resource Curse Revisited'. Research Paper. London: Chatham House.

Thelen, K. (1999). 'Historical Institutionalism in Comparative Politics'. Annual Review of Political Science, 2: 369-404.

Tylecote, A. (2015). 'Institutions Matter: But which Institutions? And How and Why Do They Change?' Journal of Institutional Economics. DOI: 10.1017/S1744137415000478.

Van der Ploeg, F. (2008). Challenges and Opportunities for Resource Rich Countries. OxCarre Research Paper 2008-05. Oxford Centre for the Analysis of Resource Rich Economies, University of Oxford.

Van der Walle, S. (2005). Measuring Bureaucratic Quality in Governance Indicators. Paper for the 8th Public Management Research Conference, Los Angeles, 29 September-1 October.

Weinthal, E., and P. Jones Luong (2006). 'Combating the Resource Curse': An Alternative Solution to Managing Mineral Wealth'. Perspectives on Politics, 4(1): 35-53.

Whitfield, L., L. Buur, O. Therkildsen, and A. Mette Kjær (2015). The Politics of African Industrial Policy: A Comparative Perspective. Cambridge University Press.

Williamson, O.E. (1985). The Economic Institutions of Capitalism. New York: The Free Press.

Williamson, O.E. (2000). 'The New Institutional Economics: Taking Stock, Looking Ahead'. Journal of Economic Literature, 38(3): 595-613. 
Woolcock, M., L. Pritchett, and J. Isham (2001). 'The Social Foundations of Poor Economic Growth in Resource-rich Countries'. In R. Auty (ed.), Resource Abundance and Economic Development. UNU-WIDER Studies in Development Economics. Oxford University Press.

United Nations (2011). Guiding Principles on Business and Human Rights. Implementing the United Nations 'Protect, Respect and Remedy' Framework. New York and Geneva: UN Human Rights Office of the High Commissioner. 